\title{
Control Design of Wind Turbine System Using Fuzzy Logic type 2 Trapezoid Non Simetrical Controller for Voltage 20 Kv Transfer Low voltage 400 Volt
}

\author{
Hilmansyah \\ Department of Electrical Engineering \\ Polytechnic Negeri Balikpapan \\ E-mail: Hilmansyah_555@Gmail.com
}

\begin{abstract}
Abstrak
Jurnal ini menyajikan tentang sistem turbin angin untuk mendapatkan secara berkelanjutan sumber tegangan listrik $20 \mathrm{kV}$. Keluaran dari sistem turbin angin dikontrol melalui dc-dc boost converter untuk memproduksi tenaga yang maskimum serta untuk memperoleh MPP (Maximum Power Point). Keluaran dari konverter dikontrol menggunakan logika fuzzy untuk memperoleh MPP (Maximum Power Point) turbin angin, demikian efisiensi sistem turbin angin bisa meningkat. Sistem turbin angin terkoneksi tegangan listrik $20 \mathrm{kV}$. Dari simulasi menggunakan Matlab 2010 bisa disimpulkan bahwa kontroller itu bisa meningkatkan tenaga sampai $75 \%$, tenaga maksimum dari turbin angin.
\end{abstract}

Kata Kunci : Maximum Power Point, Turbin Angin, Logika Fuzzy

\begin{abstract}
This paper presents a system wind turbine in order to have continously electricity supply for $20 \mathrm{kV}$ grid. Output wind turbine controlled by $d c$-dc boost converter to produce maximum power in order to obtain the MPP (Maximum Power Point). Output of the converter is controlled by fuzzy logic to obtain the MPP (Maximum Power Point) wind turbine, thus the efficiency wind turbine can be increased. The system of wind turbine is connected to $20 \mathrm{kV}$ grid. From the simulation using matlab 2010 can be concluded that the controller can shift power to $75 \%$ maximum power of wind turbine.
\end{abstract}

Keywords: MaximumPowerPoint, Wind Turbine, Fuzzy Logic controller

\section{Introduction}

In this century, the increasing of energy demand followed by the increasing cost of fuel. A lot of people are tend to use renewable energy to generate electric energy. Renewable energy is used due to affordable price and produce less pollution $\left(\mathrm{CO}_{2}\right)$ in the environment, furthermore less greenhouse effect can be reached [10].

Renewable energy has been explored to meet the load demand. Utilization of renewable energy is able to secure longterm sustainable energy supply, and reduce local and global atmospheric emissions.
Wind Turbine (WT) units are become the promising technologies for supplying the load demand in remote and isolated area. However, there are several weakness faced by such resources. One of the weaknesses is the power generated by wind energy is influenced by the weather conditions. The variations of power generated by these sources may not match with the time distribution of demand.

Wind turbine (WT) that clean, and abundantly available in nature, are being developed to affordable price and largescale use. But, highly considered to 
increase the system efficiency wind turbine as well as to improve the system reliability wind turbine. There are two ways to increase the system efficiency of wind turbine. First, improve the materials to have high conversion efficiency at low cost.

\section{Research Method}

\section{Hybrid System Photovoltaic and Wind Turbine}

The system consists of wind turbine (WT) connected to $20 \mathrm{kV}$ grid, while for wind turbine (WT) have input $\mathrm{v}$ (wind speed) and V (actual voltage wind turbine). Fuzzy logic for controlling boost converter to shift the actual voltage to the optimum voltage.

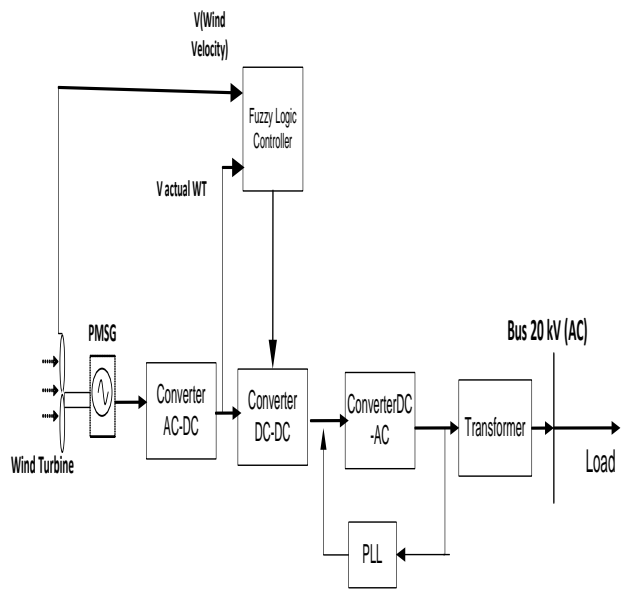

Figure 1. Hybrid system of photovoltaic and wind turbine $20 \mathrm{kV}$ Grid connected

\subsection{Wind Turbine}

The wind is air moves that caused by unequal heating of the sun to earth surface. Air moves is wind kinetic energy that can be used for various needs, like a generator's prime mover of electricity generation by wind turbine conversion system[10]. The total of wind power that caught by turbine depend on size of rotor blade turbine and wind speed, can be shown in this equation :

$P_{w t}=\frac{1}{2} \pi R^{2} \rho v^{3}$
$R$ is radius of wind turbine, $\rho$ air density and $v$ wind speed. Mechanic power that produced by turbine determined bi wind turbine efficiency, can be shown in this equation :

$P_{m}=\frac{1}{2} \eta \pi \rho R^{2} v^{3}$

According to Bezt limit, maximum efficiency of wind turbine is 0.57. This value determined by power coefficient and Tip Speed Ratio (TSR) [10]. Power coefficient is mechanical power ratio on turbine with wind power that caught by wind turbine's rotor blade and TSR is speed ratio of wind turbine's rotor blade with wind speed, explain on this equation :

$C_{p}=\frac{P_{m}}{P_{w t}}$

$\lambda=\frac{\omega_{w} R}{v}$

$C_{p}$ is power coefficient, $\lambda$ is Tip Speed Ratio (TSR) and $\omega_{w}$ is angular speed of turbine. Connection between mechanical power with power coefficient and TSR explain on the equation below :

$P_{m}=\frac{1}{2} \pi \rho C_{p}(\lambda, \beta) R^{2} v^{3}$

$\beta$ is angle of wind turbine's rotor blade to wind direction. Mechanical power is power that will be transferred to generator. The value of power coefficient determined by TSR and angle of wind turbine's rotor blade. Connection of TSR, power coefficient, and angle of wind turbine's rotor blade shown in this equation :

$C_{p}(\lambda, \beta)=c_{1}\left(\frac{c_{2}}{\lambda_{i}}-c_{3} \beta-c_{4}\right) e^{\frac{-c_{5}}{\lambda_{i}}}+c_{6} \lambda$

(6)

With

$\frac{1}{\lambda_{i}}=\frac{1}{\lambda+0.08 \beta}-\frac{0.035}{\beta^{3}+1}$ 
$c_{1}$ and $c_{2}$ is constant. The value of TSR determined by rotating speed of turbine and wind

Speed [10]. The value of power coefficient and TSR variating on a wind speed, depend on turbine rotation. Mechanical torque that used to rotate the generator determined by rotating speed of turbine and mechanical power of turbine, explained in this equation :

$T_{m}=0.5 \pi \rho C_{p} \beta R^{2} v^{3}$

Wind turbine that using a gearbox, power and mechanical torque on the generator shaft is :

$P_{m}=\omega_{m} \frac{T_{\text {shaft }}}{\eta_{\text {gear }}}$

$T_{m}=\frac{T_{\text {shaft }}}{\eta_{\text {gear }}}$

$\omega_{m}=\omega_{m} \eta_{\text {gear }}$

$T_{\text {shaft }}$ is mechanical torque in low speed shaft, $T_{m}$ is mechanical torque in generator's shaft, $\omega_{w}$ angular speed of turbine, $\omega_{m}$ is mechanical speed of generator's shaft and $\eta_{\text {gear }}$ gearbox efficiency.

\subsection{Wind Turbine Characteristic}

Characteristic plot of wind turbine using this following diagram :

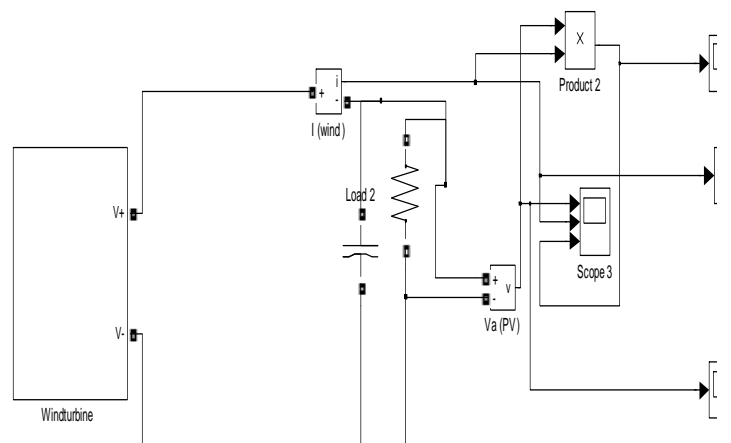

Figure 2. Block Diagram Characteristic Plot of Wind Turbine

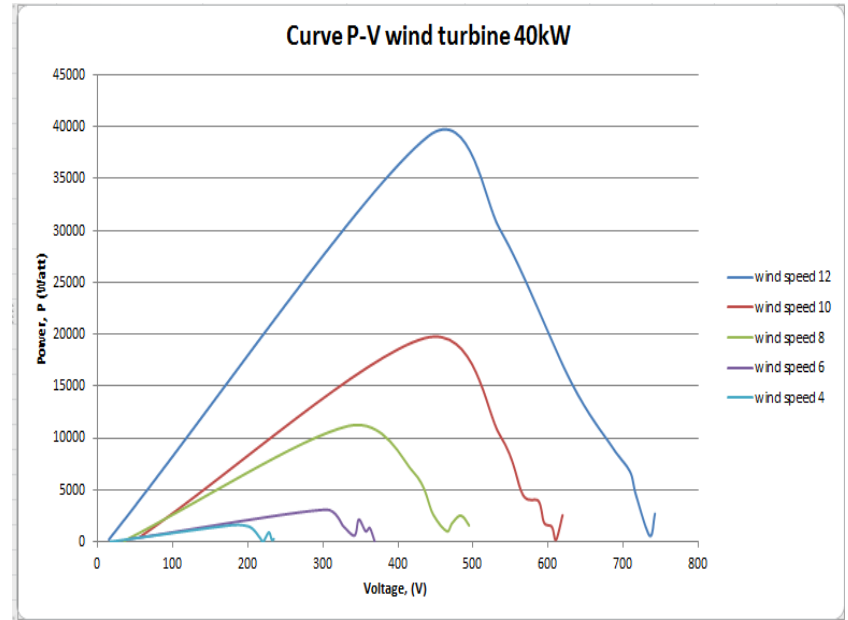

Figure 3. Wind Turbine Characteristic

\section{Results and Analysis}

3.1Kontroler Fuzzy Logic Type 2 model trapezoid

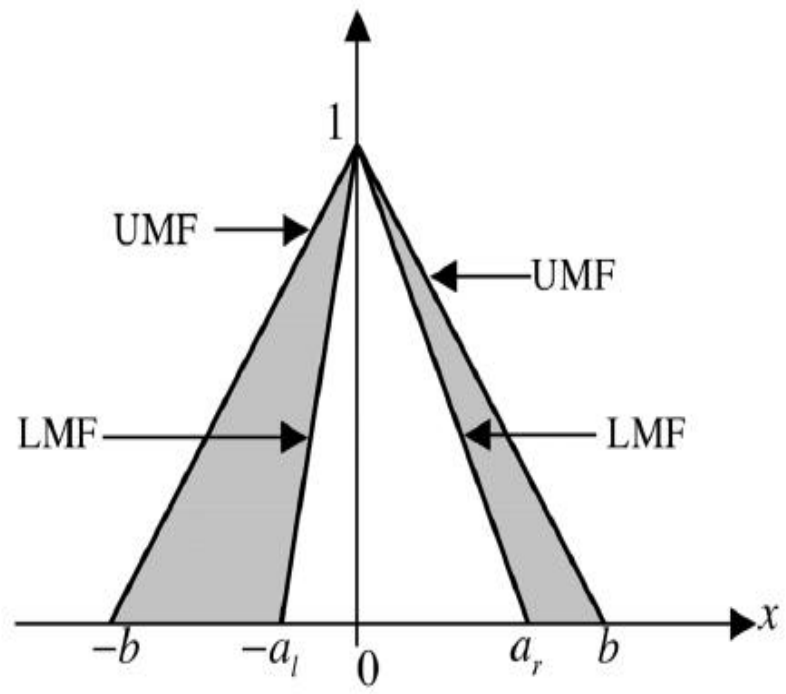

Figure 4. Fuzzy Logic Controller

Fuzzy logic controller is used to control duty cycle so the suitable duty cycle can be obtained for boost converter to get optimal voltage.

Control design of MPPT from Wind Turbine can be seen below: 


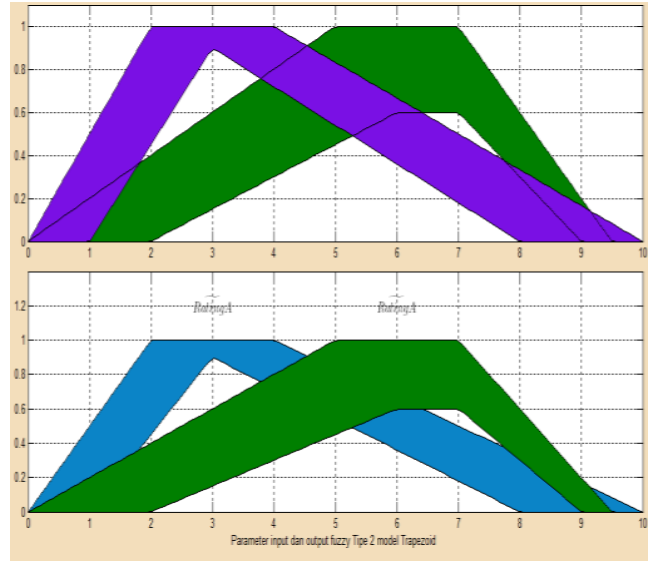

Figure 5. Wind Turbine Fuzzy Logic Type 2 model trapezoid

Fuzzy logic contains of input and output, for fuzzy input Figure 5 contains of two inputs that are voltage and wind speed. The membership showed below

Figure 5. Duty Cycle Membership Function (output fuzzy logic).From membership above can be made the rule of fuzzy logic as below

1.If (Voltage is V1) and (wind_speed is v1) then (duty_cycle is D1) (1)

2. If (Voltage is V2) and (wind_speed is v2) then (duty_cycle is D2) (1)

\section{Simulation Results}

\subsection{Simulation SystemWind Turbine 20 $\mathrm{kV}$ grid connected}

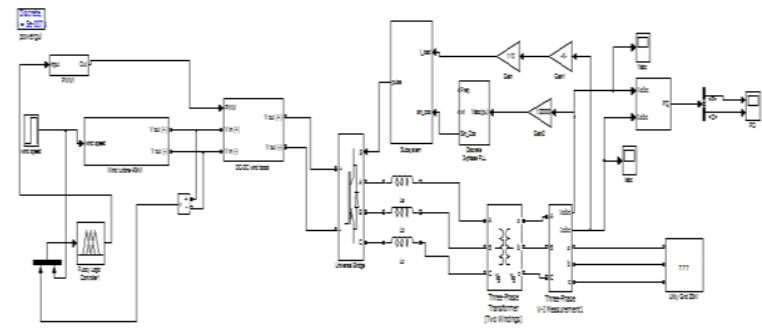

Figure 6. Simulation of System Wind Turbin connected grid $20 \mathrm{kV}$

The design above composed of wind turbine that controlled using fuzzy logic control to obtain MPP for system. The maximum power condition wind turbine isdistributed to $20 \mathrm{kV}$.

The simulation results for wind turbine can be seen in Figure 7. Below :

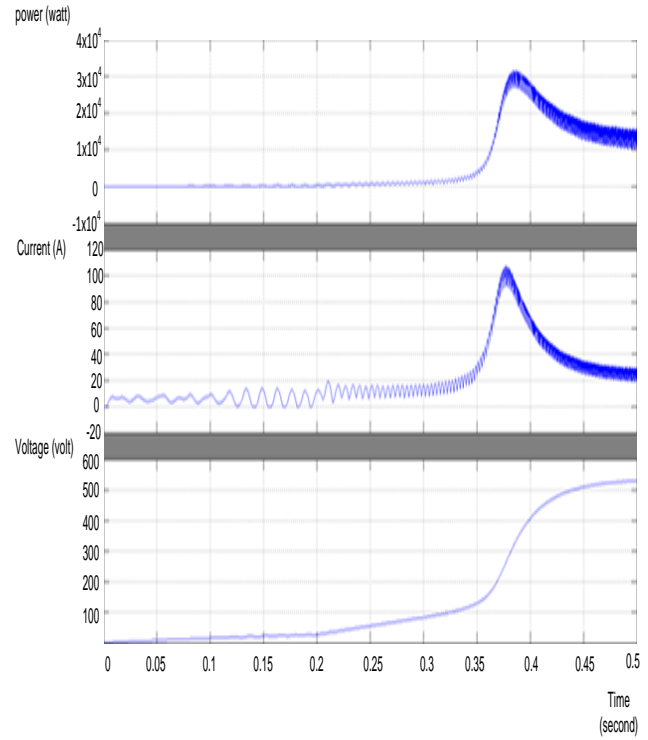

Figure 6. Output from wind turbine generator (power, current, voltage)

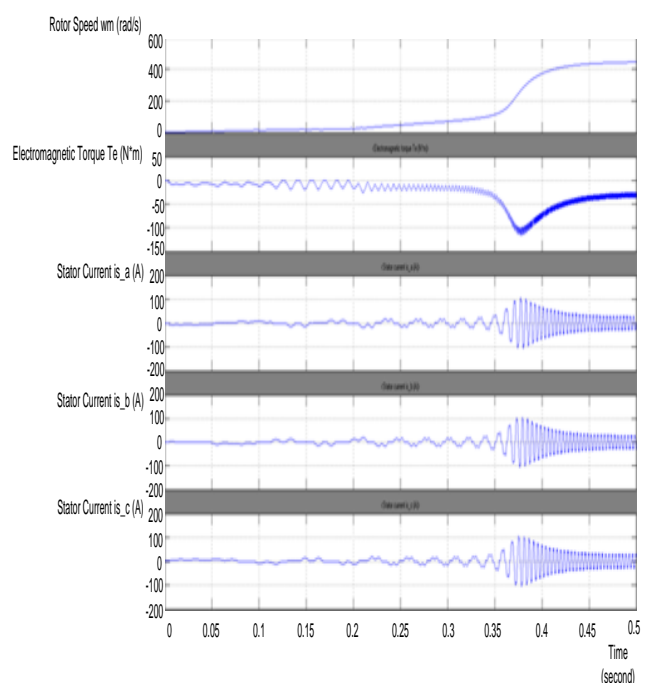

Figure 7. Specification of permanent magnet syncronous generator

From figure 7, it can be seen that the fuzzy logic controller can control power into maximum, with wind speedsof $8 \mathrm{~m} / \mathrm{sin}$ thesecondto zeros, wind speed $8 \mathrm{~m} / \mathrm{sto} 0.1 \mathrm{~s}$ , the wind speedof $12 \mathrm{~m} / \mathrm{sto} 0.2 \mathrm{~s}$, wind speedof $12 \mathrm{~m} / \mathrm{sto} 0.3 \mathrm{~s}$, windvelocityof 12 
$\mathrm{m} / \mathrm{sto} 0.4 \mathrm{~s}$, and thewind speed of $8 \mathrm{~m} / \mathrm{sto}$ $0.5 \mathrm{~s}$.

That From figure can be seen that wind turbine not in maximum power. So there is much losses in wind turbine, to shift power to maximum power the wind turbine connected to maximum power point converter.

The simulation results for Output Boost converter ( $\mathrm{V}$ input, I out, $\mathrm{V}$ out)can be seen in Figure 8. Below :

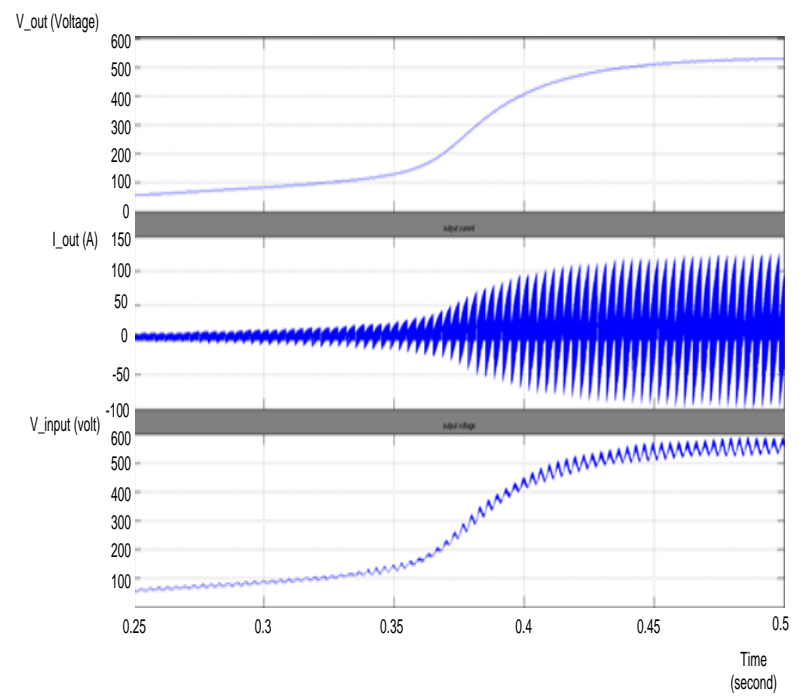

From figure 8, it can be seen that the fuzzy logic controller can control boost converter in optimum voltage 500 Volt, so the power of wind turbine can be shifted to maximum power.

The simulation results for Power (PQ) output to grid can be seen in Figure 8 . Below :

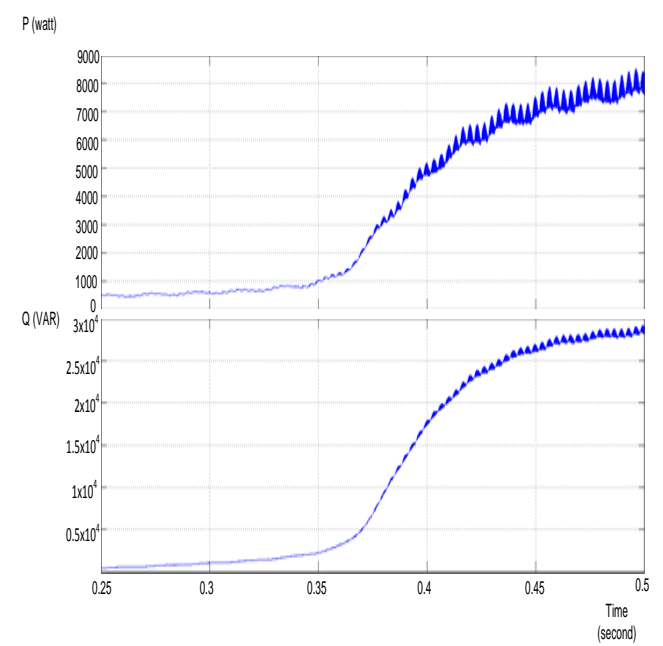

Figure 8. Power (PQ) output to grid

From figure 13, it can be seen that the fuzzy logic controller can control power into maximum:

$\mathrm{P}=7000$ watt, $\mathrm{Q}=27000 \mathrm{VAR}$, the maximum power of wind turbine is supplied to $20 \mathrm{kV}$.

\section{Conclusion}

Design of a systemwind turbine controlled by fuzzy logic can contribute to the power grid $20 \mathrm{kV}$ in accordance with the energy produced in optimum condition.By varying the input wind speed for wind turbines system can generate maximum power. The system of wind turbine can provide power $75 \%$ their energy to $20 \mathrm{kV}$.

\section{References}

Hussein Al-Masri, FathiAmoura, "Feasibility Study of a Grid Connected Hybrid Wind/PV System" International Journal of Applied Power Engineering (IJAPE), Vol. 2, No. 2, August 2013, pp. 89 98ISSN: 2252-8792, 2013.

HUANG Wang-jun, ZENG Zhi-gang, ZHOU Hui-fang, TEN Yuan-jiang, Li Li, "Modeling and Experimental Study on Grid-Connected Inverter for Direct Drive Wind Turbine" TELKOMNIKA, Vol. 11, No. 4, April 2013, pp. 2064 2072 e-ISSN: 2087-278X, 2013. 